\title{
Reconstruction of Legal Policies for the Implementation of Fines Based on Islamic Values
}

\author{
Ira Alia Maerani ${ }^{1}$, Nuridin $^{2}$ and Eko Soponyono ${ }^{3}$ \\ \{ira.alia@unissula.ac.id $\left.{ }^{1}\right\}$ \\ Universitas Islam Sultan Agung (UNISSULA), Semarang, Indonesia ${ }^{123}$
}

\begin{abstract}
This paper aims to analyze the policy of implementing criminal law in the criminal system in Indonesia and to analyze the formulation of the law on the implementation of criminal fines in the Draft Criminal Code (RKUHP) in the future and to find out the concept of Diyat in Islamic Criminal Law as an effort to reconstruct policy. criminal fines in order to fulfill a sense of justice in society. Especially in order to provide protection for victims. The approach method used is juridical normative with a statutory approach; conceptual approach; and a comparative approach. The type of data used is secondary data and the nature of the descriptive analysis research. Types of crime (criminal system) as stipulated in the Criminal Code and the Criminal Procedure Code stipulate that fine are one of the main types of crimes. Fines are considered quite effective in providing a deterrent effect and providing alternative solutions to justice besides imprisonment (the crime of eliminating the freedom of others). However, what needs to be considered in an effort to reconstruct this fine is a policy to provide protection for victims and this has been regulated in Islamic Criminal Law in the concept of Diyat. Therefore, this article will make Islamic values in Islamic Criminal Law as a reference in comparative studies.
\end{abstract}

Keywords: Reconstruction; Criminal Implementation Law; Criminal Fines; Diyat; Islamic Values

\section{Introduction}

Positive Criminal Law Science (ius constitutum) consists of material criminal law; Formal Criminal Law; and Criminal Implementation Law (Penitentiary Law). Types of crime (criminal system) according to Article 10 of the Criminal Code consist of the main and additional crimes. Basic Crime consists of: Death Penalty; Prison Criminal; Criminal Cage: V; Criminal Fines; and Criminal Covering. Additional Penalties consist of: Revocation of certain rights; Confiscation of certain items; and Announcement of Judge Decisions.

Straftometing contains regulations on types of crime (strafsoort); the size of the crime / the severity of the punishment (strafmaat); and the form or mode of punishment (strafmodus). The provisions regarding criminal law enforcement (penitentiary law) have not been regulated in a single book such as the Criminal Code as one of the sources of material criminal law, and the Criminal Code as a source of formal criminal law. Criminal law enforcement (penitentiary law) is still regulated in a fragmentary manner. So that it is considered not fulfilling the legal codification.

Legislation products that regulate capital punishment are regulated in Law (hereinafter abbreviated as: UU) No. 5 of 1969 in conjunction with Law no. 2 / Pnps / 1964 jo Chief of 
Police Regulation No. 12 of 2010 concerning the Implementation of the Death Penalty, namely by being shot to death. With the enactment of this regulation, Article 11 of the Criminal Code which regulates capital punishment by hanging by the executioner on the gallows is declared invalid.

Prison punishment is regulated in Law no. 12 of 1995 concerning Corrections. Penalty of confinement is regulated in Article 18 - Article 29 of the Criminal Code. Criminal fines are regulated in Article 30 of the Criminal Code, Perppu No. 16 of 1960, Perppu No. 18 of 1960 and Supreme Court Regulation (Perma) No. 2 of 2012 concerning Adjustment of Limits of Minor Crime and Number of Fines in the Criminal Code. The Criminal Code is regulated in Law no. 20 of 1946 concerning the Covering Punishment. (Ira Alia Maerani, 2018: 45)

Types of crime (criminal system) as regulated above indicate that fines are one of the main types of crimes. This research will discuss the focus of the study of fines and will not discuss other types of main crimes. Including not discussing additional crimes. The explanation above shows that the provisions on criminal law enforcement are still fragmented in various legislative products. The meaning of fragmented means fraction, fragment, bit by bit, cutting into pieces, dividing into pieces, dividing. Meanwhile, the word fragmentary means incomplete, separated. (John M. Echols and Hasan Shadily, 2006: 256) Fines become interesting to be studied scientifically in relation to the latest developments in society. Where there are new developments in criminal law enforcement policies that are quite prominent. The development of alternative sanctions from imprisonment or deprivation of a person's freedom, has turned to fines. Fines are applied mainly to not minor crimes or criminal acts punishable by imprisonment of 1 year.

Fines are considered more solutive than imprisonment. As it is known, imprisonment causes excessive burden on the state. So much is the State Budget (APBN) that is set aside for feeding, health, training of prisoners or now known as the Correctional Assistance Citizens (WBP). Especially when the Covid-19 pandemic broke out. Fines are expected to provide a more solution than imprisonment in which prisoners are resistant to contracting the corona virus. Like what happened to the Kerobokan Prison in Bali, where hundreds of prisoners were exposed to the corona virus (Kompas, 24/10/2020)

The short duration of imprisonment in prisons is considered to be less of a deterrent effect for criminal offenders (inmates). The prisoner's brief introduction to other inmates in the correctional facility allows the prisoner to become "contaminated". So an anecdote appears that says, "Going to prison for stealing sandals, leaving prison to become a corruptor." So that from the point of view of the purpose of punishment, imprisonment is considered to be less of a deterrent effect or less effective.

For this reason, there are alternative penalties besides eliminating this independence, namely fines. Criminal fines have the privilege of being able to be imposed on people, they can also be imposed on corporations (legal entities). Where there are laws that amend and add to the Criminal Code which regulates the subject of criminal acts in the form of individuals or corporations. As Law no. 31 of 1999 in conjunction with Law no. 20 of 2001 concerning the Eradication of Corruption; UU no. 8 of 2010 concerning Prevention and Eradication of the Crime of Money Laundering; UU no. 21 of 2007 concerning the Eradication of the Crime of Trafficking in Persons; UU no. 35 of 2009 concerning Narcotics; UU no. 17 of 2016 in conjunction with Law no. 35 of 2014 in conjunction with Law no. 23 of 2002 concerning Child Protection; and various other legal products. Meanwhile, the Criminal Code only recognizes people as subjects of criminal acts from the subjective element in the form of the word "whoever". 
Another feature of fines is seen from the point of view of its benefits in the form of actions (maatregel) that provide protection, improvement, education, treatment to the community. This fine can be shifted into compensation; compensation money for damages; peace to forgiveness. In order to restore balance in society. The concept of this fine in Islamic Criminal Law is known as Diyat.

Especially when the Covid-19 pandemic broke out. Thousands of inmates are given assimilation to prevent transmission of the corona virus in prisons. Reporting in the media mentions that a few of them have committed criminal acts again. This fact proves that imprisonment is not the only key to restore balance in society. Therefore, it is hoped that a fine is the best alternative solution. So it is necessary to reconstruct the best formulation according to the values of the Indonesian people based on Pancasila.

Based on the above background, especially to examine holistically the provisions of fine penalties in the current positive criminal law (ius constitutum); the provisions for criminal fines are regulated in the RKUHP as law that will apply in the future (ius constituendum); as well as a comparative study of Islamic Criminal Law regulates the provisions on diyat as material for the reconstruction of the reform of the national Criminal Law. So, this research entitled, "Reconstruction of the Legal Policy Implementation of Fines Based on Islamic Values."

\section{Formulation of The Problem}

a. How is the legal policy for the implementation of fines in positive criminal law?

b. What is the legal policy for implementing criminal fines in the Criminal Law that will apply in the future (Draft Criminal Code / RKUHP) 2019?

c. How is the effort to reconstruct the legal policy for the implementation of fines based on Islamic values?

\section{Research Purposes}

a. To find out and analyze legal policies for the implementation of fines in the positive criminal law (ius constitutum)

b. To find out and analyze the legal policies for the implementation of criminal fines stipulated in the Criminal Code which will apply in the future in the 2019 RKUHP (ius constituendum).

c. To reconstruct the legal policy for the implementation of criminal fines based on Islamic values.

\section{Usefulness of Research}

This research is expected to provide benefits / uses both theoretically and practically;

a. Theoretical Use

Finding a new theory of legal policies for the implementation of criminal fines in the effort to develop Indonesian-style criminal law, in accordance with the identity, philosophy and ideology of the Indonesian nation, namely Pancasila.

b. Practical Uses

Providing input to the executive, legislative, judiciary, academia and the public to consider how effective the current fine-law enforcement policies are, which some still maintain colonial law products, complement existing research materials on types of crimes (strafsoort), severe lightness of the crime (strafmaat), and the way the crime is carried out (strafmodliteit / strafmodus). 


\section{Method}

\section{Approach Method}

The approach method in this study uses a normative juridical approach. In normative legal research, several approaches are used, namely the statutory approach (statute app approach), the conceptual approach (conceptual approach) and the comparative approach (comparative approach) (Johny Ibrahim, 2005: 444).

\section{Research Specifications}

The research specification carried out is normative legal research or literature law research. Normative legal research or literature put forward by Soerjono Soekanto includes research on the level of horizontal synchronization and legal comparisons (Soerjono Soekanto, 1985: 14). In research on the level of horizontal synchronization it is intended to examine the extent to which the level of harmony between equal statutory provisions is positive law.

\section{Nature of Research}

The nature of the research used by researchers is descriptive analytical. In addition to the research conducted, this is a prescriptive and applied research. As a prescriptive science, law studies the aims of law, the values of justice, the validity of legal rules, legal concepts, and legal norms. As an applied science, law determines standard procedures, provisions, and guidelines for implementing legal rules.

\section{Data Sources}

The legal research used is secondary data, namely data in the form of products of statutory regulations, legal documents, court decisions, literature books, and legal dictionaries.

\section{Legal Research Materials}

Legal research materials can be divided into:

a. Primary legal material consisting of legislation, official records, or minutes in the making of laws and judges' decisions. The primary legal materials for this legal research are: $\mathrm{Al}$ Qur'an; Hadith; Criminal Code (KUHP); Draft Criminal Code (RKUHP); Supreme Court Regulation (Perma) No. 2 of 2012 concerning Adjustment of Limits of Minor Crime and Number of Fines in the Criminal Code.

b. Secondary legal materials, in the form of all legal publications which are official documents. These legal publications include text books, legal dictionaries, legal journals, and commentaries on court decisions. In this case the researcher uses legal journals, research results from legal circles, including legal articles on the internet.

c. Tertiary legal materials, are legal materials that support primary and secondary legal materials by providing understanding and understanding of other legal materials. The legal materials used by the researcher are large Indonesian, English and legal dictionaries.

\section{Data Collection Methods}

After the issue of legal stipulation emerged, researchers searched for relevant legal materials after the legal issues faced. In this case the researcher uses a statutory approach, what is done is looking for regulations regarding or related to the topics discussed, namely the Criminal Code, RKUHP, the Supreme Court Regulations (Perma) No. 2 of 2012 concerning Adjustment of Limits of Minor Crime and Number of Fines in the Criminal Code. 


\section{Data Analysis Method}

After the researcher collects legal materials, is described and connected in such a way, the researcher will draw the conclusions proposed or the problems that have been formulated. Furthermore, the legal materials are analyzed to carry out reconstruction efforts against criminal fines based on Islamic values.

\section{Discussion and Assessment}

\subsection{Provisions for Criminal Fines in Positive Criminal Law}

Fines are one of the main crimes in the Indonesian criminal system. Fines are one of the main types of criminal sanctions that are threatened and are primarily aimed at the assets or assets of a perpetrator for violating the provisions of the applicable Criminal Law (I.A. Budivaja and Y. Bandrio, 2020: 78). Criminal fines in the Criminal Code are a type of criminal sanction with a different percentage and type of punishment. Starting from Article 104 to Article 488 of the Criminal Code for Crimes (Book II) and starting from Article 489 to Article 569 of the Criminal Code for Violations (Book III). (Suhariyono, 1993: 171)

As well as being charged with the perpetrator of the violation, fines are also imposed on the perpetrator of the crime which sometimes is an alternative or cumulative. The minimum amount that can be imposed on a fine is set at twenty-five cents, while the maximum amount has no provisions. Regarding criminal fines are regulated in Article 30 of the Criminal Code which reads as follows:

a. "The punishment shall be a minimum fine of three rupiah and seventy-five cents.

b. If a fine is not paid, it is replaced by imprisonment.

c. The length of the substitute imprisonment is at least one day and a maximum of six months.

d. In a judge's decision, the duration of substitute imprisonment is stipulated thus; if the fine is seven rupiah and fifty-two cents or imprisonment, the count is one day; if it is more than five rupiahs and fifty cents, every seven rupiahs and fifty cents is counted at the most for one day, as well as the remaining seven rupiah and fifty cents that are not enough.

e. If there is an increase in the penalty of fine due to concurrency or repetition, or because of the provisions of Article 52, the substitute imprisonment for a maximum of eight months.

f. The punishment of substitute imprisonment must not exceed eight months."

As part of the law that adds to the Criminal Code, namely the enactment of Government Regulations in Lieu of Law No. 16 of 1960 (LN 1960-50) which came into effect on April 14, 1960 stipulated that: "The words" vijf en twinting gulden "in articles 364, 373, 384, and 407 Paragraph (1) of the Criminal Code amended to be "two hundred and fifty rupiah" as regulated in Article 1 Perppu No. 16 of 1960.

The provision for a fine of IDR 250.00 is based on Government Regulation in Lieu of Law No. 18 of 1960 must be read in rupiah currency and multiplied to be fifteen times. This provision does not apply to the number of fines in the provisions of criminal acts that have been included in economic crimes. Bearing in mind the principle of lex specialist derogate legi generale. The narrow definition of economic crime is a crime that is legally regulated in Emergency Law No. 7 of 1995 concerning Investigation, Prosecution and Economic Crime Court.

Meanwhile, economic crimes in a broad sense are all criminal acts other than Emergency Law No. 7 of 1955 which has economic patterns or motives or which may negatively affect 
economic activity and healthy state finances. In foreign terms it is often called: economic crimes, crime as business, business crimes, abuse of economic power.

Economic crime is divided into 3 types:

a. Property crimes: Acts that threaten the property of a person or the state (act that threathen property held by private persons or by the state):

b. Regulatory crimes: Actions that violate government regulations

c. Tax Crime: violations of the liability or violation of requirements related to the preparation of reports according to tax laws (violations of the liability or reporting requirements of the tax laws)

Based on the information above, that the last fine was changed in 1960 through Perppu No. 16 and Perppu No. 18 of 1960. Since then, the criminal penalty has no longer changed. This causes the implementation of fines to be ineffective (Indung Wijayanto, 2015).

Several factors cause the legislative policy regarding fines which cannot support the implementation of criminal fines effectively, namely:

a. The threat of fine in the Criminal Code is generally relatively light. The maximum criminal fines for crimes range between Rp. 900 and Rp. 150,000 - even this is only found in two articles, namely Articles 251 and 403 of the Criminal Code (Indung Wijayanto quoted from Budijava and Bandrio, 2010)

b. Changes and increases in the threat of fines against several crimes in the Criminal Code and especially outside the Criminal Code, has little meaning because it is not accompanied by changes in the overall system for the implementation of criminal fines (Bakhri, 2010 in Indung Wijayanto)

Considering that the value of the rupiah in the Criminal Code is not in accordance with the current price of gold and to facilitate law enforcers, especially judges in providing justice to the cases they are judging, the Supreme Court issued Supreme Court Regulation (Perma) No. 2 of 2012 concerning Adjustments to the Limits of Minor Crime and the Number of Fines in the Criminal Code (Indung Wijayanto, 2015)

Adjusting the value of the currency which is not in accordance with current conditions, in the issuance of Supreme Court Regulation Number 2 of 2012 on February 27, 2012) Article 1 explains that the words "two hundred and fifty rupiah" in article 364 of the Criminal Code (KUHP), 373 KUHP (Minor Embezzlement), 379 KUHP (Light Fraud), 384 KUHP (Profits from Fraud), 407 KUHP (Minor Damage), and 482 KUHP (Light Penadahan) read as two million five hundred thousand rupiah. Article 3 also explains that each maximum amount of fine punishable under the Criminal Code except Article 303 paragraph (1) and paragraph (2) is multiplied to be a thousand times.

Contents of Supreme Court Regulation No. 2 of 2012 is more about adjusting the limits of minor crimes and the number of fines in the Criminal Code so that the system for implementing fines according to Articles 30 and 31 of the Criminal Code is still maintained. In fact, the system for the implementation of fines in the Criminal Code contains several weaknesses, namely:

a. There are no provisions regarding other measures to ensure the implementation of a fine, for example by seizing or confiscating his property or assets, except by imprisonment in substitute of a fine;

b. The maximum substitute imprisonment is only 6 months which can become 8 months if there is a weighting of the fine, even though the penalty imposed or imposed by the judge is quite high up to tens of millions;

c. There are no guidelines or criteria for imposing fines, both in general and for special matters, for example for fines imposed on children who have not worked. 
It is also worth noting in the process of implementing Perma No. 2 of 2012 is the socialization, harmonization and synchronization of related regulations and coordination between law enforcement agencies. So, it is expected to eliminate polemics in society (Haryanto, Gunarto, Ira Alia Maerani: 2018). Included in this is testing the effectiveness of the implementation of fines. Considering that a study has concluded that the application or implementation of fines in Indonesia has not been effective or has not been maximized because law enforcers or judges tend to prefer imprisonment rather than fines. (Sulistyo Utomo, Ira Alia Maerani, 2019)

\subsection{Projection of Legal Implementation of Fines in RKUHP 2019}

The legal provisions for the implementation of criminal fines that will apply in the future (ius constituendum) in this article discuss the rules in the 2019 Draft Criminal Code (hereinafter abbreviated as RKUHP 2019). The 2019 RKUHP is a long series of struggles by national criminal law experts in an effort to revise colonial legal products. The product of colonial law in question is the Criminal Code (KUHP) or Wetboek van Strafrecht (W.v.S.) which in the Netherlands itself has been amended hundreds of times.

The decades of struggle of these criminal law experts should be well appreciated by studying juridical arguments in their law in mind. These criminal law experts take the essence of the values of the Indonesian nation. So that the norms that are formed are adjusted to the value order of the Indonesian nation. The values contained in the Pancasila ideology are: the value of the One Godhead; Fair and Civilized Human Values; The Value of Indonesian Unity; Popular Values Led by Wisdom in Deliberations / Representatives; and by realizing the value of Social Justice for All Indonesians.

A belief that the struggle will succeed in time is manifested in the persistence of the head of the Criminal Code Revision Formulation Team, Prof. Dr. H. Muladi, S.H. The Criminal Code Revision Formulation Team was steadfastly fighting for the revision of the Criminal Code, which was a revision of colonial products. Even though Prof. Muladi died on December 31,2020 , studying the knowledge of dozens of national criminal law experts contained in the 2019 RKUHP is a hope towards a national legal product that takes the essence of the values of the Indonesian nation itself. Not originating from the values of the colonial nation, which are of course different. So it is hoped that when the ius constituendum (the law that you aspire to) becomes the ius constitutum (positive law) then this legal product will be well socialized. For that the Indonesian people can accept the law properly as expected.

Regarding the fines stipulated in the 2019 RKUHP, fines are one of the main crimes stipulated in Article 65 of the 2019 RKUHP. Article 65 states there are 5 types of crimes that fall into the main criminal category, namely: imprisonment; closure penalty; supervision crime; criminal fine; and social work crimes. Criminal sequence indicates the severity or lightness of the crime.

Criminal fines are an amount of money that must be paid by the convict based on a court decision (Article 78 Paragraph 1 of the 2019 RKUHP). Fines are divided into 8 categories. If no special minimum is determined, the minimum fine is IDR 50,000.00 (fifty thousand rupiah).

Article 79 Paragraph (1) RKUHP 2019 regulates 8 categories of fines, namely:

1) Category I, IDR 1,000,000.00 (one million rupiah);

2) Category II, Rp.10,000,000.00 (ten million rupiah);

3) Category III, Rp.50,000,000.00 (fifty million rupiah);

4) Category IV, IDR 200,000,000.00 (two hundred million rupiah);

5) Category V, Rp. 500,000,000.00 (five hundred million rupiah); 
6) Category VI, Rp.2,000,000,000.00 (two billion rupiah);

7) Category VII, IDR 5,000,000,000.00 (five billion rupiah);

8) Category VIII, IDR 50,000,000,000.00 (fifty billion rupiah).

Regarding the possibility of changing the value of money, the amount of the fine is determined by a Government Regulation (PP). The provisions in accordance with the values of the 2nd Pancasila Principle, Fair and Civilized Humanity, in Article 71 Paragraph (1) of the 2019 RKUHP states that a fine is applied if the convict who commits a criminal act carries a prison sentence of less than 5 years. The criminal penalty decision by this judge after considering the purpose of punishment and the guidelines for the punishment as stipulated in Articles 51, 52 and 54 of the 2019 RKUHP.

Article 51 of the 2019 RKUHP regulates the objectives of punishment, namely:

a. "Preventing criminal acts by upholding legal norms for the protection and protection of the community;

b. Socializing the convicted person by providing guidance and guidance to become a good and useful person;

c. Resolving conflicts arising from criminal acts, restoring balance, and creating a sense of security and peace in society; and

d. Cultivate a sense of remorse and free the guilt of the convict. " Criminalization also aims not to degrading human dignity (Article 52 RKUP 2019).

The judge is obliged to pay attention and consider when imposing a sentence. The factors that are considered by the judge as stipulated in Article 54 Paragraph (1) of the 2019 RKUHP:

a. the form of wrongdoing of the perpetrator of a criminal act;

b. motives and objectives of committing a criminal act;

c. the inner attitude of the criminal offender;

d. Criminal acts are committed or unplanned;

e. how to commit a criminal act;

f. attitudes and actions of the perpetrator after committing a criminal act;

g. curriculum vitae, social conditions, and economic conditions of the perpetrator of the Criminal Act;

h. the effect of the criminal on the future of the criminal offender;

i. the influence of the criminal act on the victim or the victim's family;

j. forgiveness of the Victim and / or their family; and / or

k. the value of law and justice that lives in society.

The Pancasila values accommodated in Article 54 Paragraph (2) of the 2019 RKUHP, namely not to impose a crime or not to take action taking into account the aspects of justice and humanity seen from the lightness of the act, the personal condition of the perpetrator or the circumstances at the time the criminal act was committed.

The important thing that the judge needs to pay attention to is that the fine as referred to in the information above can only be applied if: (Article 71 Paragraph 2 of the 2019 RKUHP)

a. Without victims;

b. The victim doesn't mind;

c. Not a repeat of a criminal act.

The penalties that can be imposed based on the provisions as referred to in Article 71 Paragraph (1) of the 2019 RKUHP are a maximum fine of category V IDR 500,000,000.00 (five hundred million rupiah) and a minimum fine according to Category III (IDR 50,000,000., 00 or fifty million rupiah). This provision is regulated in Article 71 Paragraph (3) of the 2019 RKUHP. 
Fines can still be applied for repetition of crimes if the perpetrator of a criminal offense who has been sentenced to imprisonment is under 18 years of age (child). This provision is regulated according to Article 71 Paragraph (4) of the 2019 RKUHP. Although Article 71 Paragraph (2) of the RKUHP stipulates otherwise, fines cannot be applied to a criminal act repeated (recidivist). The implementation of Pancasila values is also evident in Article 80 Paragraph (1) and Paragraph (2) of the 2019 RKUHP, especially the principles of humanity and social justice. This article provides that in imposing a fine, the judge is obliged to consider the ability of the defendant by taking into account the actual income and expenditure of the defendant and does not reduce the application of the specified minimum penalty.

In fact, the penalty in installments (in installments) is applied in accordance with Article 81 Paragraph (2) of the 2019 RKUHP. This penalty is considered to be in installments in order not to burden the convicted person. The provisions of this norm are the implementation of Pancasila values, namely just and civilized humanitarian principles. The next alternative solution to the judge's decision which determines the time period in which the convict is unable to fulfill that period, the convict's wealth or income can be confiscated and auctioned off to pay off the unpaid fine. The prosecutor has the authority to confiscate and auction off. This provision is regulated in Article 81 Paragraph (3) of the 2019 RKUHP.

The imprisonment, supervisory or social work punishment can be stipulated if the confiscation and auction of the convict's wealth or income is insufficient or impossible to carry out. Provided that the said fine is not more than Rp.10,000,000 (ten million rupiah) or category II. (Article 82 Paragraph (1) RKUHP 2019)

The duration of the substitute sentence as regulated in the article above includes:

a. for substitute imprisonment, a minimum of 1 (one) month and a maximum of 1 (one) year which can be aggravated by a maximum of 1 (one) year and 4 (four) months if there is a weighting penalty due to concurrency;

b. for substitute supervision punishment, for a minimum of 1 (one) month and a maximum of 1 (one) year, the conditions as referred to in Article 76 paragraph (2) and paragraph (3) shall apply; or

c. for substitute social work punishment for a minimum of 8 (eight) hours and a maximum of 240 (two hundred and forty) hours.

The next provision in Article 82 Paragraph (3) of the 2019 RKUHP is that if at the time of serving a partially paid penalty, the length of the substitute sentence is reduced according to an equivalent measure. Regarding the equivalent size, it is regulated in Article 82 Paragraph (4) of the 2019 RKUHP, namely the calculation of the length of the substitute sentence as referred to in paragraph (3) is based on the size for each penalty of Rp 50,000.00 (fifty thousand rupiah) or less which is equivalent to:

a. one hour of substitute social work punishment; or

b. one day of supervisory or substitute imprisonment.

Article 83 Paragraph (1) of the 2019 RKUHP explains that if the confiscation and auction of assets or income has been carried out, plus the provisions regarding substitute imprisonment or substitute supervision or substitute social work cannot be carried out, a fine above category II that is not paid is replaced by imprisonment. a minimum of 1 (one) year and a maximum of as threatened for the Criminal Act concerned. Supervision punishment for a maximum of 6 (six) months and a maximum fine of $1 / 3$ (one third) for a recidivist or person who has repeatedly been sentenced to a fine for a criminal offense which is only punishable by a maximum fine of Category II. This provision is regulated in Article 84 of the 2019 RKUHP. 


\subsection{Efforts to Reconstruct the Legal Policy Implementation of Fines Based on Islamic Values}

The word "reconstruction" comes from the word "re" in Indonesian which means: once again; back; reform. Meanwhile, the word "construction" in the Big Indonesian Dictionary (KBBI) has a meaning, namely: the arrangement (model, layout) of a building (KBBI, 2007). So that the purpose of reconstruction is to rebuild, reform, fix and lead to a better direction (benefit) again. Something that is not quite right / appropriate / ideal / has not kept up with developments, should be reconstructed, fixed, considering that something that is not relevant to use does not rule out the need for renewal.

The meaning of reconstruction can be understood as renewal or re-actualization, which has three meanings, namely:

a. Reconstructing or updating with things that have been there before (reviving);

b. Reconstructing or updating something that is out of date (patchwork);

c. To reconstruct or renew with completely new forms / innovative creations. (Abu Husain Ahmad bin Faris bin Zakaria, 1979: 306)

Development or change basically requires the people to act and behave in a new way. Various qualifications can be mentioned to indicate the novelty in this behavior, such as: from colonial subjects to independent nations; from a narrow regional consciousness to become one nation. One of the ways to institutionalize this change is through overhauling the old legal system to a new one based on new legal and social principles and ideals. (Satjipto Rahardjo, 1983: 117)

Regarding the reconstruction of criminal law policy in Indonesia, in his inauguration speech for a professor at the Faculty of Law of Diponegoro University, Barda Nawawi Arief, argued that reform of Indonesian criminal law essentially means a reorientation and reform of positive criminal law seen from the concept of the central values of the Indonesian nation (from the socio-philosophical, socio-political, and socio-cultural aspects) that underlie social policies, criminal policies and law enforcement policies in Indonesia. (Barda Nawawi Arief, 25 June 1994)

The root word for policy is "wise" which means always using one's mind; clever, proficient. Policy is a series of concepts and principles that form the basis of plans for the implementation of a job, leadership and how to act (regarding organizational governance and so on); statement of ideals, objectives, principles or intentions as a guideline for management in achieving goals; bow line. (KBBI, 2007: 115)

The root word "wise" in English means; able, smart, experienced, wise, while policy means wisdom and policy. (John M. Echols and Hassan Shadily, 2006: 79)

The word policy as formulated above; the original meaning is related to:

a. government or polity, political wisdom or cunning,

b. wise, expedient or prudent conduct or management, conduct or management,

c. a principle, plan, or course of action, as pursued by a government, organization, individual, etc. (foreign policy)

d. Thus, the definition of policy contains various matters:

e. A series of concepts and principles as the basis for a work implementation plan;

f. Is a way of acting in the field of government;

g. As a statement of goals or principles ideals;

$\mathrm{h}$. As a management guide in achieving goals and also a guideline.

In addition to the four points above, it is based on the use of reason, as well as ability or intelligence (Eko Soponyono, 2010: 62-63). The term "policy" is taken from the English term 
"policy" or the Dutch term "politick." In the Popular Political Encyclopedia of Pancasila Development (Barda Nawawi Arief, 2003: 53) politics is defined as:

a. The art of regulating and administering the state and state science;

b. All policies / actions that intend to take part in state / government affairs including those concerning the form, duties and scope of state affairs;

c. Politics includes various activities in an organized system of society (especially the state; polity), which involves decision making, both regarding the objectives of the system itself and regarding its implementation. Making decisions about the objectives of the system involves choosing between alternatives and determining priorities. Decisions regarding implementation involve a variety of general and concrete policies. For its implementation, power and authority are needed which in conflict of interests can use persuasion or if necessary, coercion. Thus, after all, politics is related to power.

d. As an effort solely to build and use power. Although in reality this is often the case, power over other humans should not be a such goal, but only a means.

e. The formation and use of force must be assessed according to the goals and objectives to be achieved with it and according to how to obtain and use it and also according to whether the method of using it is according to the wishes of the person concerned or not. Because someone (adult) should not be forced to accept what others think is good for them. So, the people should not be considered as ignorant in order to know and take care of their real interests, so it must be determined. The freedom to determine one's own destiny is of a higher value than material progress. Slavery to material prosperity is less valuable than freedom despite the limited availability of goods. So political action must be held accountable to those who own the state, namely the people and ultimately to the Creator of the people. So politics must be judged ethically too. Whereas in the end, political review as an activity related to the state cannot be other than the common welfare of all the people.

f. In a broader sense, politics is defined as a way or policy (policy) to achieve certain goals.

g. Thus, in its implementation, politics involves power, rulers and strength. This fact should not be a mere goal but as a means which ultimately must bring about the common welfare of all the people. Sudarto was even more emphatic in saying that politics is inevitably subjective, depending on the views of someone who is "political". (Sudarto, 1983: 93)

The implications for the concept of public policy are described in detail below:

First, public policy is more of an act that is deliberately carried out and leads to a specific goal rather than simply as a form of behavior or deviant actions that are completely random (at random), carelessly and coincidentally but rather planned (by planed).

Second, policy essentially consists of actions that are interrelated and patterned, leading to certain goals carried out by government officials, and not decisions that stand alone. For example, policies do not only include decisions to make laws in certain fields, but are followed by more detailed decisions / technical guidelines for implementation, relating to the implementation process and the implementation mechanism for their enforcement.

Third, the policy is what the government actually does in certain fields. An ideal policy should be accompanied by firm and concrete actions to implement it. Fourth, public policy may be positive, it may be negative. In its positive form, public policy may include some form of government action intended to influence the resolution of a particular problem. While in its negative form, it may include decisions of government officials not to move, or not to take any action in matters where government intervention is really necessary (Solichin Abdul Wahab, 2016: 20-22). 
The final results of the policy are the (direct) consequences or impacts that are actually felt by the community, both those that are expected and actually felt by the community, both those that are expected (intended) and those that are not expected (unintended), as a logical consequence of their existence. action or inaction of government action in certain fields or problems in society. A public policy analyst will attempt to examine whether a particular public policy has succeeded in achieving what it should have achieved by comparing the formal (normative) objectives of the program with the reality, achievements, or performance achieved. (Solichin Abdul Wahab, 2016: 32-33).

The effort to reconstruct the legal policy for the implementation of criminal penalties based on Islamic values, of course, has made the Qur'an and Hadith the main references. The next source of law is Ar-Ra'yu (use of the minds of scholars (fuqoha), among others: Ijma ', Ijtihad, Qiyas, Istihsan, Maslahat Mursalah, Urf, and Saddud Zari'ah.

a. Ijma' the unanimity of the opinion of the fuqoha mujtahidin at one time regarding a law after the time of the Prophet Muhammad.

b. Ijtihad is a detailed description of Islamic teachings derived from the Al-Qur'an and general Hadith.

c. Qiyas, namely equating the law of a case where there is no legal stipulation with a case for which there is already legal stipulation. The similarity of legal provisions referred to is based on the existence of similarity elements with existing legal provisions and those without legal provisions called illat.

d. Istihsan is to exclude the law of an event from the law of other similar events and give it another law of a kind. The exception is made because there is a strong basis.

e. Maslahat Mursalah is a legal stipulation based on benefit (goodness, interest) which has no provisions from syara 'either general provisions or special provisions.

f. Sadduz zari'ah, which is to block / close something that is the way of damage. Meanwhile, Urf is a tradition that has been passed down from generation to generation but does not conflict with Islamic teachings.

Al-Qur'an as the main legal basis is a revelation from Allah SWT which came down in Arabic and its authenticity has been well maintained since fourteen years ago until the Day of Judgment. Even to prove its authenticity, Allah challenges anyone who doubts its authenticity and the truth of the Qur'an. Anyone who does not believe in the Qur'an to be the word of Allah, He challenges him to have that person present a letter that is similar to the Qur'an. (Juju Samsudin Saputra, 2014: 60-61).

Allah says in Al Qur'an surah Al Baqoroh Verse 23:

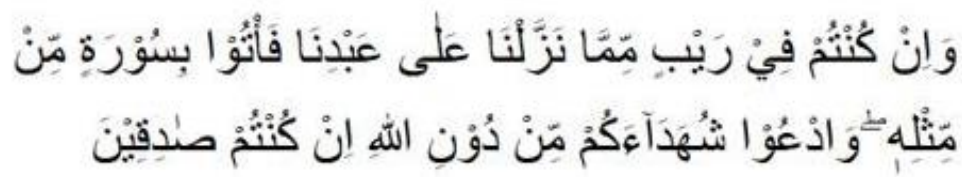

Meaning: "And if you doubt (the Qur'an) that We sent down to Our servant (Muhammad), then make a chapter like that and invite your helpers besides Allah, if you are righteous people".

His word is also in the Al Qur'an surah Al Isra' Verse 88:

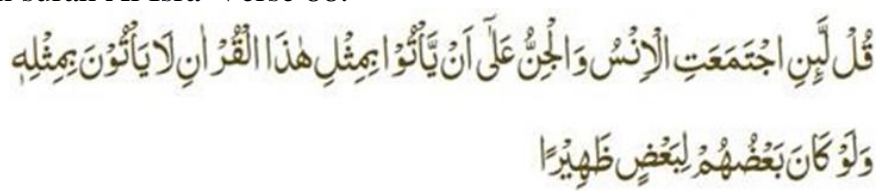


Meaning: "Say, "Indeed, if humans and jinn come together to make something similar (to) this Qur'an, they will not be able to make something like it, even if they help each other."

Related to the theme in this paper which examines fines, then in the Qur'an there is the concept of diyat in Islamic Criminal Law. Namely the provision of compensation to victims. As regulated in the Al Qur'an chapter Al Baqoroh Verse 178.

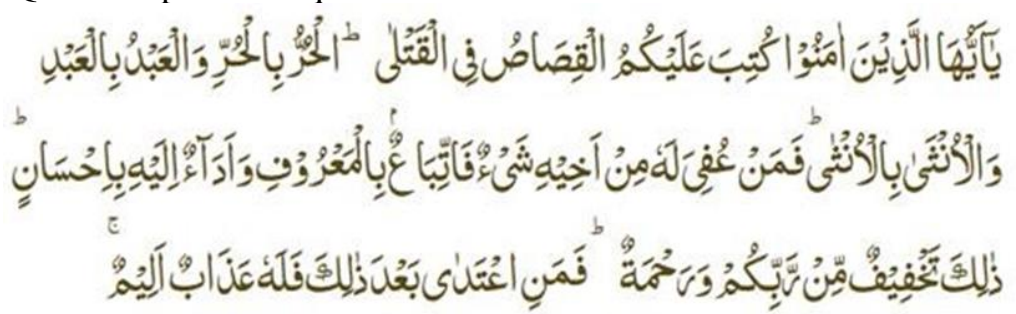

Meaning: "O you who believe! It is obligatory on you (carry out) qisas with regard to the person who is being killed. Free man and free man, slave and slave, woman and woman. But whoever gets forgiveness from his brother, let him follow it well, and pay him the diat (ransom) well (too). That is the relief and mercy of your Lord. Whoever exceeds the limit after that, then he will get a very painful punishment."

Obtaining forgiveness is a keyword for a criminal. So that qisas does not apply to him and pays diyat (ransom). Forgiveness is given by the victim. For that, the victim will receive a diyat from the perpetrator for the crime he has committed. One of the characteristics of Islamic law is to provide balance (balancing) or harmonization in society. As Alloh says in Al Qur'an surah Al Mulk Verse 3.

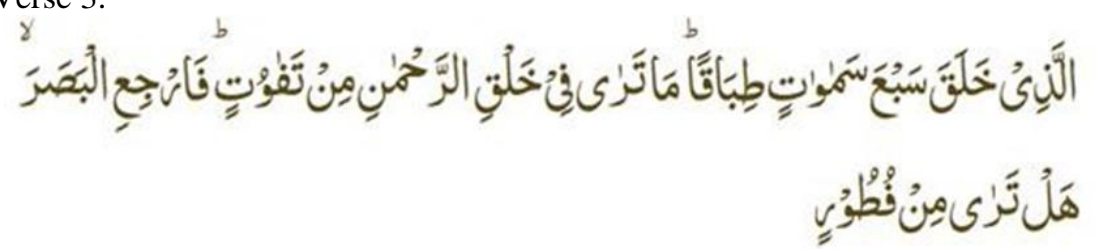

Meaning: "Who created the seven heavens in layers. You will not see anything unbalanced in God's creation, the All-Merciful. So look again, do you see something flawed?"

From the point of view of this conviction was successful. Where one of the goals is to restore the loss of balance due to criminal acts committed by the perpetrator. By returning it to the victim. For that a fine was given to the victim. The reconstruction effort of a fine is that the victim, as the main party who is harmed by the perpetrator, is the first to be asked about justice according to him. This is a reconstruction of the development of a national criminal law where victims are often neglected in the criminal justice system process. Even to the verdict against the perpetrator, the victim was only asked about the chronology of the case. Rarely are they asked and asked for an opinion of justice according to the victim.

Another positive thing that can be learned in Islamic Criminal Law is the legal certainty that is regulated in the Al-Qur'an. Fairness that is not arbitrary. However, based on the Word of Allah as the Creator, the Creator who is sure to provide the best, just and beneficial law for all creatures. Where the provisions of this Diyat have provisions, which are regulated in the Al-Qur'an and Hadith. Behind the strict sanctions and the high number of Diyat in the framework of protecting society, victims and perpetrators of criminal acts. 
There is also a side of forgiveness in Islamic Criminal Law. Pay attention to Al Qur'an chapter Al Baqoroh Verse 178 above. Whoever gets forgiveness from his brother let him follow it well and pay the diyat (ransom) well. The idea of forgiveness has been accommodated in Article 54 of the 2019 RKUHP. Where in conviction, one thing that must be considered is forgiveness of the victim and / or his family. However, the Criminal Code or Wetboek van Strafrecht (W.v.S), a legacy of the Dutch colonialists, is still valid in Indonesia, which has been independent since August 17, 1945, there is not a single article that considers the side of forgiveness. Even the victims were not asked how they think of justice.

For this reason, the 2019 RKUHP regulates criminal guidelines, namely in adjudicating a criminal case, judges are obliged to uphold law and justice. If in upholding law and justice there is a conflict between legal certainty and justice, the judge is obliged to prioritize justice (Article 53 RKUHP 2019). One of the characteristics of Islamic law is that it is jama'iyah (togetherness). This means that if the perpetrator is unable to pay the diyat, the family can contribute to solving the problem. The perpetrator takes part in and the solution to the side of the balance that has been taken by him. This is a non-penal mediation idea. Some parties call it the term alternative dispute resolution (ADR). Prioritizing deliberation to find the best justice for all parties. Restoring balance and justice for perpetrators, victims and society.

It seems that several constructive ideas of Islamic law are part of the reform of national criminal law, especially in relation to the reconstruction of the legal policy for the implementation of criminal fines. So that it is hoped that the values of justice, benefit and legal certainty will synergize in the law enforcement process in Indonesia.

\section{Conclusion}

a. The legal policy for the implementation of fines in positive criminal law is regulated in the Criminal Code and laws that add to and amend the Criminal Code. Such as Government Regulation in Lieu of Law (Perppu) No. 16 of 1960, Perrpu No. 18 of 1960, the product of legislation that regulates Economic Crime, and the Supreme Court Regulation (Perma) No. 12 of 2012 concerning Adjustments to the Limits of Minor Crime and the Number of Fines in the Criminal Code.

b. The legal policy for implementing fines in the upcoming criminal law, namely in the 2019 RKUHP, is regulated in several articles. Fines are arranged into 8 categories ranging from Rp. 1 million to Rp. 50 billion. The 2019 RKUHP also regulates criminal installments (in installments). It is expected to be an alternative solution behind the overload of correctional institutions (prisons). Fines can be imposed if there is no victim; the victim didn't mind; and not a repetition of a criminal act. The victim does not care, it is assumed that the victim has forgiven the perpetrator. For this reason, the idea of forgiveness is also accommodated in the 2019 RKUHP.

c. Legal reconstruction of the implementation of fines based on Islamic values, among others, to restore the balance process that has been taken by the perpetrator by providing a fine (diyat) to the victim. According to him, the victim was also asked for his opinion about justice. He accommodates the forgiveness side. Legal certainty is guaranteed because it is regulated in the highest source of law that maintains its originality, namely the Qur'an and Hadith. Behind the firmness of the sanctions there is protection for humans as a whole, both protection for perpetrators, victims and society. 


\section{Suggestions}

a. The Unitary State of the Republic of Indonesia (NKRI) has been independent and sovereign since August 17, 1945. It is appropriate to have a national criminal law product that accommodates the noble values of the Indonesian nation. Based on the values of Pancasila which are based on the One Godhead (religious values); Just and civilized humanity; The unity of Indonesia; Community Led by Wisdom in Deliberation / Representation; as well as by prioritizing Social Justice for All Indonesians. For this reason, all norms that apply in the State of Indonesia are actually based on the values of Pancasila. Islamic values are one of the main comparative studies considering that they have a positive correlation with the reform of the national criminal law.

b. It is time for the government not only to include the 2019 RKUHP in the National Legislation Program (Prolegnas) but also to ratify the 2019 RKUHP as a national legal product to replace the colonial-spirit KUHP (Wetboek van Strafrecht). It is time for the Republic of Indonesia which has been independent for decades to have a legal product made in Indonesia which takes the essence of the values of the Indonesian nation. The Criminal Code which originated in the Netherlands, and previously originated from France, has been amended hundreds of times in its home country. Why are we still using colonial legal products?

c. The purpose of punishment is to provide a deterrent effect on the perpetrator, restore the balance process that has been taken by the perpetrator, uphold justice and truth. For this reason, the criminal penalty policy is actually a fine (compensation) given to the victim whose rights have been taken away by the perpetrator. This is an input in reforming the national criminal law where there are legal protection measures against victims who have been deprived of their rights by the perpetrator of the crime. Fines are not given to the state but to the victims. This is one of the ideas of balance in Islamic Criminal Law. From the point of view, the punishment was successful. Perpetrators take part in providing solutions to crimes that have been committed that have taken away the rights of the victim and / or the victim's guardian. Legal protection for the community, victims and perpetrators is realized. Create balance, justice and harmony in society.

\section{References}

[1] Abu Husain Ahmad bin Faris bin Zakaria, 1979, Mu'jam Maqayis al-Lughah, Vol.1, Dar al-Fikr li al-Thaba'ah wa al-Nasyr, Beirut

[2] Barda Nawawi Arief, 2003, Kapita Selekta Hukum Pidana, PT. Citra Aditya Bakti, Bandung

[3] Beberapa Aspek Pengembangan Ilmu Hukum Pidana (Menyongsong Generasi Baru Hukum Pidana), Pidato Pengukuhan Guru Besar pada Fakultas Hukum Universitas Diponegoro, Semarang, 25 Juni 1994

[4] Departemen Pendidikan Nasional, 2007, Kamus Besar Bahasa Indonesia, edisi Ketiga, Balai Pustaka, Jakarta

[5] Eko Soponyono, 2010, Kebijakan Sistem Pemidanaan Yang Berorientasi Pada Korban, Disertasi,Program Doktor Ilmu Hukum (PDIH) Fakultas Hukum Universitas Diponegoro (Undip), Semarang

[6] Haryanto, Gunarto, Ira Alia Maerani, Implementasi Peraturan Mahkamah Agung Nomor 2Tahun 2012 Tentang Penyesuaian Batasan Tindak Pidana Ringan Dan Jumlah Denda Dalam KUHP Di Kepolisian Resor Rembang (Studi Kasus Pada Tindak Pidana Pencurian Ringan, Jurnal Hukum Khaira Ummah, Vol. 13. No. 1 Maret 2018, Diterbitkan Oleh Magister Ilmu Hukum Fakultas Hukum Universitas Islam Sultan Agung (UNISSULA) Semarang 
[7] Indung Wijayanto, Kebijakan Pidana Denda di KUHP dalam Sistem Pemidanaan Indonesia, Jurnal Pandecta, Volume 10 No. 2 Desember 2015, http://journal.unnes.ac.id/nju/index.php/pandecta DOI http://dx.doi.org./10.15294/pandecta.v.10i2

[8] Ira Alia Maerani, 2018, Hukum Pidana \& Pidana Mati, Unissula Press, Semarang

[9] Johnny Ibrahim, 2005, Teori dan Metodologi Penelitian Hukum Normatif, Bayumedia Publishing, Surabaya

[10] John M. Echols dan Hassan Shadily, 2006, Kamus Inggris Indonesia, Cetakan XXVIII, PT Gramedia Pustaka Utama, Jakarta

[11] Juju Samsudin Saputra, 2014, Pidana Denda, Deepublish, Yogyakarta

[12] Satjipto Rahardjo, 1983, Masalah Penegakan Hukum Suatu Tinjauan Sosiologis, Sinar Baru, Bandung

[13] Soerjono Soekanto, 1985, Penelitian Hukum Normatif, Suatu Tinjauan Singkat, PT Raja Grafindo Persada, Jakarta.

[14] Solichin Abdul Wahab, 2016, Analisis Kebijakan Dari Formulasi ke Penyusunan Model-Model Implementasi Kebijakan Publik, Cetakan Kelima, PT. Bumi Aksara, Jakarta

[15] Sudarto, 1983, Hukum Pidana dan Perkembangan Masyarakat, Sinar Baru, Bandung Sulistyo Utomo, Ira Alia Maerani, Application of Criminal Penalties in Child

[16] Protection Law in the State Court Of Ngawi, Jurnal Daulat Hukum, Vol. 2 No. 4 Tahun 2019, Desember 2019, Diterbitkan Oleh Magister Ilmu Hukum Fakultas Hukum Universitas Islam Sultan Agung (UNISSULA), Semarang,

[17] http://lppm- unissula.com/jurnal.unissula.ac.id/index.php/RH/article/view/8351, DOI: http://dx.doi.org/10.30659/jdh.v2i4

[18] Undang-Undang Dasar Negara Republik Indonesia (UUD NRI) Tahun 1945.

[19] TAP MPR No. 1 Tahun 2003 tentang Peninjauan Terhadap Materi dan Status Hukum Ketetapan MPRS dan MPR RI Tahun 1960 Sampai Dengan Tahun 2002.

[20] Undang-Undang No. 12 Tahun 2011 tentang Pembentukan Peraturan Perundang- undangan.

[21] Undang-Undang No. 39 Tahun 1999 tentang Hak Asasi Manusia (HAM) Undang-Undang No. 12 Tahun 1995 tentang Pemasyarakatan

[22] Undang-Undang No. 5 Tahun 1969 tentang Pernyataan Berbagai Penetapan Presiden dan Peraturan Presiden sebagai Undang-Undang

[23] Undang-Undang No. 2/Pnps/1964 tentang Tata Cara Pelaksanaan Pidana Mati yang Dijatuhkan oleh Pengadilan di Lingkungan Peradilan Umum dan Militer

[24] Undang-Undang No. 1 Tahun 1946 tentang Peraturan Hukum Pidana jo UU No. 73 Tahun 1958 tentang Menyatakan Berlakunya Undang-Undang No. 1 Tahun 1946 Republik Indonesia tentang Peraturan Hukum Pidana Untuk Seluruh Wilayah Indonesia dan Mengubah Kitab Undang-Undang Hukum Pidana

[25] Undang-Undang No. 20 Tahun 1946 tentang Hukuman Tutupan

[26] Peraturan Pemerintah Pengganti Undang-Undang (Perppu) No. 16 Tahun 1960

[27] Peraturan Pemerintah Pengganti Undang-Undang (Perppu) No. 18 Tahun 1960

[28] Peraturan Mahkamah Agung (Perma) No. 2 Tahun 2012 tentang Penyesuaian Batasan Tindak Pidana Ringan dan Jumlah Denda dalam KUHP

[29] Rancangan Kitab Undang-Undang Hukum Pidana (RKUHP) Tahun 2019 2021. 